\title{
Drying rates of Rubi grapes submitted to chemical pretreatments for raisin production
}

\author{
Vânia Regina Nicoletti Telis(1) ${ }^{(1)}$ ânia Araújo Lourençon(1) ${ }^{(1)}$ Ana Lúcia Gabas ${ }^{(2)}$ and Javier Telis-Romero(1)
}

\begin{abstract}
(1)Universidade Estadual Paulista Júlio de Mesquita Filho, Dep. de Engenharia e Tecnologia de Alimentos, CEP 15054-000 São José do Rio Preto, SP, Brazil. E-mail: vanianic@ibilce.unesp.br, javier@ibilce.unesp.br (2)Universidade de São Paulo, Fac. de Zootecnia e Engenharia de Alimentos, Dep. de Engenharia de Alimentos, Caixa Postal 23, CEP 13630-900 Pirassununga, SP, Brazil. E-mail: gabas@usp.br
\end{abstract}

\begin{abstract}
The objective of this work was to determine the most appropriated chemical treatment to be used to dry grapes cv. Rubi for raisin production. Drying curves for convective drying with air at $50^{\circ} \mathrm{C}$, in a tray drier, were obtained for grapes submitted to chemical pretreatments with different concentrations of potassium carbonate and olive oil, and different dipping times, according to factorial designs. Convective drying curves were also obtained for grapes pretreated in aqueous suspensions of soybean lecithin, at varied lecithin concentrations and dipping times. Page model was adjusted to the experimental drying curves, and the calculated drying times showed that the best pretreatment consisted in dipping grapes for 2 minutes in a $5 \%$ olive oil and $6 \% \mathrm{~K}_{2} \mathrm{CO}_{3}$ emulsion, at $50^{\circ} \mathrm{C}$, which resulted in a drying time close to that of the pretreatment with $2.5 \%$ of olive oil, but with a lower consumption of this substance. In addition, the immersion of grapes in an aqueous suspension of $2 \%$ soy lecithin, at $50^{\circ} \mathrm{C}$, for 5 minutes, resulted in a total drying time slightly higher than the most effective pretreatment.
\end{abstract}

Index terms: Vitis vinifera, drying kinetics, soybean lecithin, olive oil, dipping treatments.

\section{Taxas de secagem de uva Rubi submetida a pré-tratamentos químicos para a produção de passas}

\begin{abstract}
Resumo - O objetivo deste trabalho foi selecionar o pré-tratamento químico mais apropriado para a secagem de uvas cv. Rubi para a produção de passas. Foram obtidas curvas de secagem convectiva com ar a $50^{\circ} \mathrm{C}$, em um secador de bandejas, para uvas submetidas a pré-tratamentos químicos com diferentes concentrações de carbonato de potássio e azeite de oliva, e diferentes tempos de imersão, de acordo com planejamentos fatoriais. Também foram obtidas curvas de secagem convectiva, para uvas pré-tratadas em suspensões aquosas de lecitina de soja, em várias concentrações de lecitina e diferentes tempos de imersão. O modelo de Page foi ajustado às curvas de secagem experimental, e os tempos de secagem calculados mostraram que o melhor prétratamento consistiu na imersão das uvas por 2 minutos, em uma emulsão de $5 \%$ de azeite de oliva e $6 \%$ de $\mathrm{K}_{2} \mathrm{CO}_{3}$, a $50^{\circ} \mathrm{C}$, o que resultou em tempos de secagem próximos aos do pré-tratamento com $2,5 \%$ de azeite de oliva, mas com um menor consumo dessa substância. Além disso, a imersão das uvas em uma suspensão aquosa de $2 \%$ de lecitina de soja, a $50^{\circ} \mathrm{C}$, por 5 minutos, resultou em um tempo de secagem total apenas levemente superior ao do pré-tratamento mais efetivo.
\end{abstract}

Termos para indexação: Vitis vinifera, cinética de secagem, lecitina de soja, azeite de oliva, pré-tratamentos químicos.

\section{Introduction}

Drying grapes by sun, shade or hot air, is carried out in many countries that produce raisins, usually employed in breakfast cereals, dairy, bakery, confectionery, and nutritional bars (Ramos et al., 2004). Almost all raisin consumed in Brazil is imported, but the production of table grapes has been increasing, and there is a great potential to use surplus or out-of-standard fruits to produce raisins, reducing losses of fresh fruits and aggregating value to the product (Gabas et al., 1998).

Brazilian production of table grapes can be divided in two major groups: the fine grapes (Vitis vinifera), mainly represented by cultivars such as Itália and its mutations Rubi, Benitaka and Brasil, in addition to Red Globe and some seedless cultivars, and the rustic grapes 
(Vitis labrusca), of which the most famous cultivars are Isabel and Niagara (Almeida, 2003; Nachtigal, 2003). Three new cultivars of seedless grapes, that are ideal for raisin production, adapted to the tropical climate, were recently presented (Camargo, 2003).

The waxy cuticle of grape skin controls the rate of moisture diffusion through the berries and, in order to accelerate drying, chemical treatments are applied to remove or modify this cuticle and increase grape skin permeability to water (Gabas et al., 1999; Pangavhane et al., 1999). The first dipping mixture consisted of olive oil and wood ash, but was substituted by an emulsion made up of a solution of approximately $2.5 \%$ food grade potassium carbonate $\left(\mathrm{K}_{2} \mathrm{CO}_{3}\right)$ and $1.5-2.0 \%$ of commercial "grape dipping oil" (Ponting \& McBean, 1970). This oil is a mixture of about $70 \%$ of ethyl esters of $\mathrm{C}_{16}$ and $\mathrm{C}_{18}$ fatty acids with free oleic acid and emulsifiers. The composition of this emulsion has probably been achieved by trial and error plus tradition, along with the practice of adding $\mathrm{K}_{2} \mathrm{CO}_{3}$ and dipping for 3 minutes. The active components are the esters and the $\mathrm{K}_{2} \mathrm{CO}_{3}$, which also assists in emulsification by neutralizing the free oleic acid in the oil to form soap (Grncarevic \& Lewis, 1976).

Bolin \& Stafford (1981) succeeded in improving grape drying rates with a methyl oleate: $\mathrm{K}_{2} \mathrm{CO}_{3}$ (1:1) mixture, whereas increasing carbonate levels increased drying rates. Gabas et al. (1999) found that increasing concentration of ethyl oleate between 0 and $3 \%$, in a solution of $2 \% \mathrm{CaCO}_{3}$, increased drying rates and resulted in raisins with a less collapsed structure. Different alkaline substances at different concentrations and temperatures, with or without addition of olive oil, were investigated by Pahlavanzadeh et al. (2001), who obtained the shortest drying time and best quality raisins by dipping grapes in a $5 \%$ solution of $\mathrm{K}_{2} \mathrm{CO}_{3}$, at $42^{\circ} \mathrm{C}$. They alerted that skin damage might result from pretreatment with high alkaline solutions. Di Matteo et al. (2000) proposed a physical treatment with superficial abrasion of grape peel and found it to be as effective as chemical dipping methods in reducing drying times.

Conventional chemical pretreatments are based on the action of surfactants, present in dipping emulsions; it would be of interest to test the effectiveness of other surfactants. Lecithin is a GRAS (generally regarded as safe) emulsifier composed of different phospholipids, glycolipids, carbohydrates and triglycerides and is largely used in foods (Fennema, 1996). Soy lecithin is a coproduct of degumming solvent extracted of soybean oil and could be a natural alternative surfactant to be applied in grape drying pretreatments. For Brazilian producers, a treatment based in soy lecithin dispersions would be economically advantageous, since olive oil and the other commercial "dipping oils" are imported ingredients.

Mathematical modeling of the dehydration process is very useful in design and optimization of dryers. The most widely used theoretical model that describes drying kinetics of food materials is the solution of Fick's second law of diffusion (Nicoleti et al., 2001). Nevertheless, for high moisture content materials such as fruits and vegetables, this analytical solution - obtained considering constant diffusivity and volume - is not always applicable, since shrinkage and diffusivity as functions of moisture content need to be taken into account. To overcome this problem without making use of complex numerical solutions, empirical models have been applied and Page model is frequently used (Parti, 1998).

The objective of this work was to obtain drying curves and to compare drying rates of Rubi grapes pretreated in potassium carbonate/olive oil mixtures and in soy lecithin/water dispersions.

\section{Material and Methods}

Ripe, fresh grapes (Vitis vinifera) cv. Rubi were obtained at the local market in São José do Rio Preto, SP, Brazil. The soluble solids content was around $15.8^{\circ} \mathrm{Brix}$ and moisture content around $0.84 \mathrm{~kg}$ water per kilogram of wet material.

Chemical pretreatments consisted of immersing grape berries, during a pre-determined time interval, in aqueous suspensions of commercial olive oil and $\mathrm{K}_{2} \mathrm{CO}_{3}$, or in aqueous dispersions of commercial unbleached soybean lecithin, according to two-level factorial designs (Box et al., 1978) with independent variables and respective levels given in Table 1 .

Solutions of the desired concentration of $\mathrm{K}_{2} \mathrm{CO}_{3}$ were prepared in distilled water and heated at $50^{\circ} \mathrm{C}$, on a hot plate with magnetic stirring. Olive oil was then slowly poured into this solution, which was kept under continuous agitation during dipping of grapes. Aqueous dispersion of lecithin was carried out in a similar manner, with lecithin being directly poured into distilled water at $50^{\circ} \mathrm{C}$ under stirring. The temperature of all treatments was kept constant at $50^{\circ} \mathrm{C}$.

The drying equipment was a pilot scale tray drier, which consisted of three basic sections - an airflow system, a drying air heating section and a drying chamber 
(Figure 1). The drying compartment consisted of four square metal trays, placed perpendicularly to the airflow. Air was forced through an axial blower, with air velocity being measured by means of an anemometer. A set of electrical resistances was installed to heat the air. A digital thermometer (Full Gauge, model Penta) measured dry bulb temperature just before air flowing through in drying trays. Relative humidity of the ambient air and just of the air before flowing through in drying chamber was measured by thermo-hygrometers (Lutron, model HT-3004). A 'honeycomb’ was installed before the drying chamber to allow better distribution of air through the product.

The berries were placed in a single layer over the tray and inserted into the dryer cabinet, after desired operating conditions had been achieved. The tray containing samples was weighed at regular time intervals. Drying runs were carried out at a constant temperature of $50^{\circ} \mathrm{C}$ and air velocity of $1 \mathrm{~m} \mathrm{~s}^{-1}$. The initial moisture content of grapes was determined gravimetrically, using a vacuum oven (Marconi, model MA-030) at $60^{\circ} \mathrm{C}$ and $110 \mathrm{~mm} \mathrm{Hg}$ for 48 hours. In order to determine the equilibrium moisture content, drying runs were conducted until changes in sample mass were less than $0.1 \mathrm{~g}$.

Page model (equation 1) was fitted to experimental drying curves by non-linear regression, using the software Satistica v.5.0 (Statsoft, 1995):

$$
\mathrm{M}=\frac{\mathrm{X}-\mathrm{X}_{\mathrm{eq}}}{\mathrm{X}_{0}-\mathrm{X}_{\mathrm{eq}}}=\exp \left(-\mathrm{kt}^{\mathrm{n}}\right)
$$

in which, $\mathrm{M}$ is the dimensionless moisture, $\mathrm{X}$ is the moisture content at a certain time $\mathrm{t}, \mathrm{X}_{0}$ and $\mathrm{X}_{\text {eq }}$ are the initial and equilibrium moisture contents, respectively, and $\mathrm{k}$ and $\mathrm{n}$ are the Page drying coefficients, which determine the precise shape of the drying curve. While neither

Table 1. Two level factorial designs for analysis of the effect of different pretreatment conditions on drying rates of grapes.

\begin{tabular}{llccc}
\hline Investigated effects at each set of drying & Independent & \multicolumn{3}{c}{ Level } \\
\cline { 3 - 5 } experiments & variable & $(-1)$ & $(0)$ & $(+1)$ \\
\hline $1^{\text {st }}$ set: analysis of the effect of olive oil & Olive oil (\%) & 0.5 & 1.5 & 2.5 \\
and $\mathrm{K}_{2} \mathrm{CO}_{3}$ concentrations & $\mathrm{K}_{2} \mathrm{CO}_{3}(\%)$ & 2.0 & 4.0 & 6.0 \\
\hline $2^{\text {nd }}$ set: analysis of the effect of olive oil & Olive oil (\%) & 0.5 & - & 2.5 \\
concentration and immersion time & Time (min) & 0.5 & - & 2.0 \\
\hline $3^{\text {rd }}$ set: analysis of the effect & Soy lecithin (\%) & 2.0 & - & 4.0 \\
$\begin{array}{l}\text { of soy lecithin concentration and } \\
\text { immersion time }\end{array}$ & Time (min) & 2.0 & - & 5.0 \\
\hline
\end{tabular}

of these parameters has a direct physical significance, empirical regression equations have been developed relating both parameters to drying conditions and raw material moisture content (Hossain \& Bala, 2002; Wang, 2002).

According to Parti (1998), the drying rate for the Page model is given by:

$\frac{\mathrm{dX}}{\mathrm{dt}}=\left(-\mathrm{knt}^{\mathrm{n}-1}\right)\left(\mathrm{X}-\mathrm{X}_{\mathrm{eq}}\right)$,

and a modified drying coefficient could be defined as:

$\mathrm{k}^{*}=\mathrm{knt}^{\mathrm{n}-1}$

If $\mathrm{n}<1, \mathrm{k}^{*}$ decreases during drying process. Thus, higher values of $\mathrm{k}$ could be used to more closely approximate the diffusion equation in the initial stages of drying, without overpredicting drying in the later stages. If $n>1$, lower values of $k$ might be adopted, without subestimating the drying curve at the end of the process.

The quality of the model adjustment was evaluated by the correlation coefficient $\mathrm{R}^{2}$, and the root mean square of residuals, RMS (Lewicki, 2000), calculated as:

$\mathrm{RMS}=100 \sqrt{\frac{\sum\left[\left(\mathrm{M}_{\mathrm{obs}}-\mathrm{M}_{\mathrm{est}}\right) / \mathrm{M}_{\mathrm{obs}}\right]^{2}}{\mathrm{~N}}}$

in which, $\mathrm{M}_{\mathrm{obs}}$ and $\mathrm{M}_{\mathrm{est}}$ are, respectively, the values of dimensionless moisture observed and estimated by the model, and $\mathrm{N}$ indicates the number of experimental points used in the regression procedure.

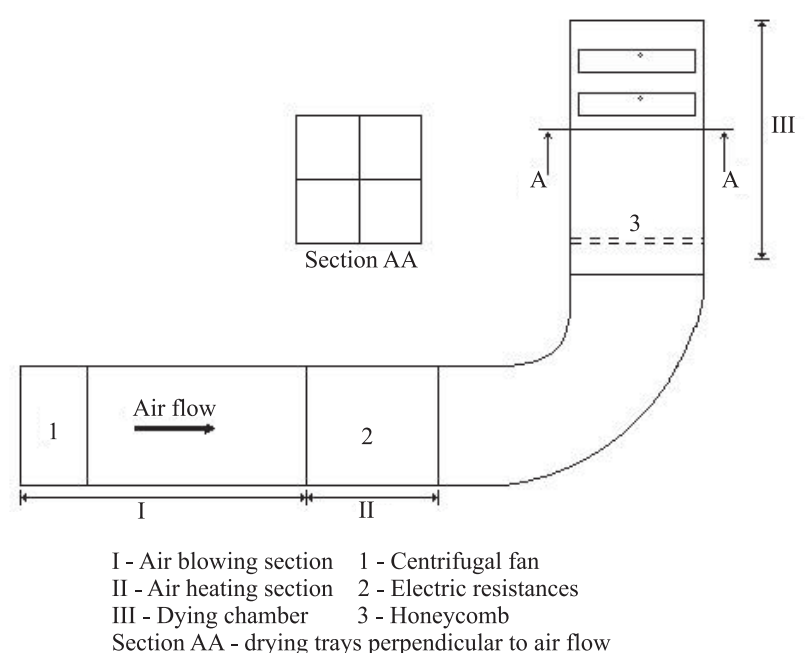

Figure 1. Schematic diagram of resistive dryer with crossed airflow. 


\section{Results and Discussion}

Drying curves for grapes, submitted to different pretreatment emulsions at $50^{\circ} \mathrm{C}$, were obtained and compared with a drying curve determined for untreated grapes (Figure 2). A first set of experiments was carried out according a two-level factorial design with a central point, varying concentrations of olive oil and $\mathrm{K}_{2} \mathrm{CO}_{3}$ and keeping constant the immersion time of 30 seconds (Table 1). The resulting drying curves showed that the applied pretreatments were effective in accelerating the drying process, with lower moisture contents at the same drying time being attained by grapes treated with a $2.5 \%$ olive oil and $6 \% \mathrm{~K}_{2} \mathrm{CO}_{3}$ emulsion (Figure $2 \mathrm{~A}$ ).

Although the adjustment of Page model (equation 1) to experimental drying curves resulted in correlation coefficients higher than 0.99 (Table 2), there was a lack of fitting in the final stage of drying, where the model underpredicted the experimental drying curves (Figure 2). Some RMS values (Table 2) were higher than $25 \%$, which was appointed by Lewicki (2000) as the maximum limit for acceptance of an adjustment model. It should be considered, however, that in the last part of drying curves, the observed moisture contents that should be inserted in the denominator of equation (4) are very low, causing RMS to be increased in spite of a good fit to the most part of the curves.

After evaluation of parameters $k$ and $n$ of Page equation for each drying condition, the model was used to estimate drying times necessary to obtain raisins with final moisture content around $14 \%$ in wet basis (Table 2). These calculations were carried out considering the initial moisture content of $84 \%$ (wet basis) - that corresponds to the average value observed in all experimental runs and the equilibrium moisture content of $1.4 \%$ (wet basis) - obtained from the average final moisture content determined in drying runs.

The effect of olive oil and $\mathrm{K}_{2} \mathrm{CO}_{3}$ concentrations, with immersion time of 30 seconds on the necessary drying time to attain $14 \%$ moisture content (wet basis), may be clearly observed in a surface plot (Figure $3 \mathrm{~A}$ ). The statistical analysis of the results indicated that only the olive oil concentration had a significant effect at $5 \%$ level of significance, with shorter drying times at higher olive oil concentrations.

Based on the results of the first set of experiments, it was concluded that an immersion time of 30 seconds had not been enough to cause a great reduction in drying times, which were still very long. Additional tests were then carried out increasing immersion time of berries in
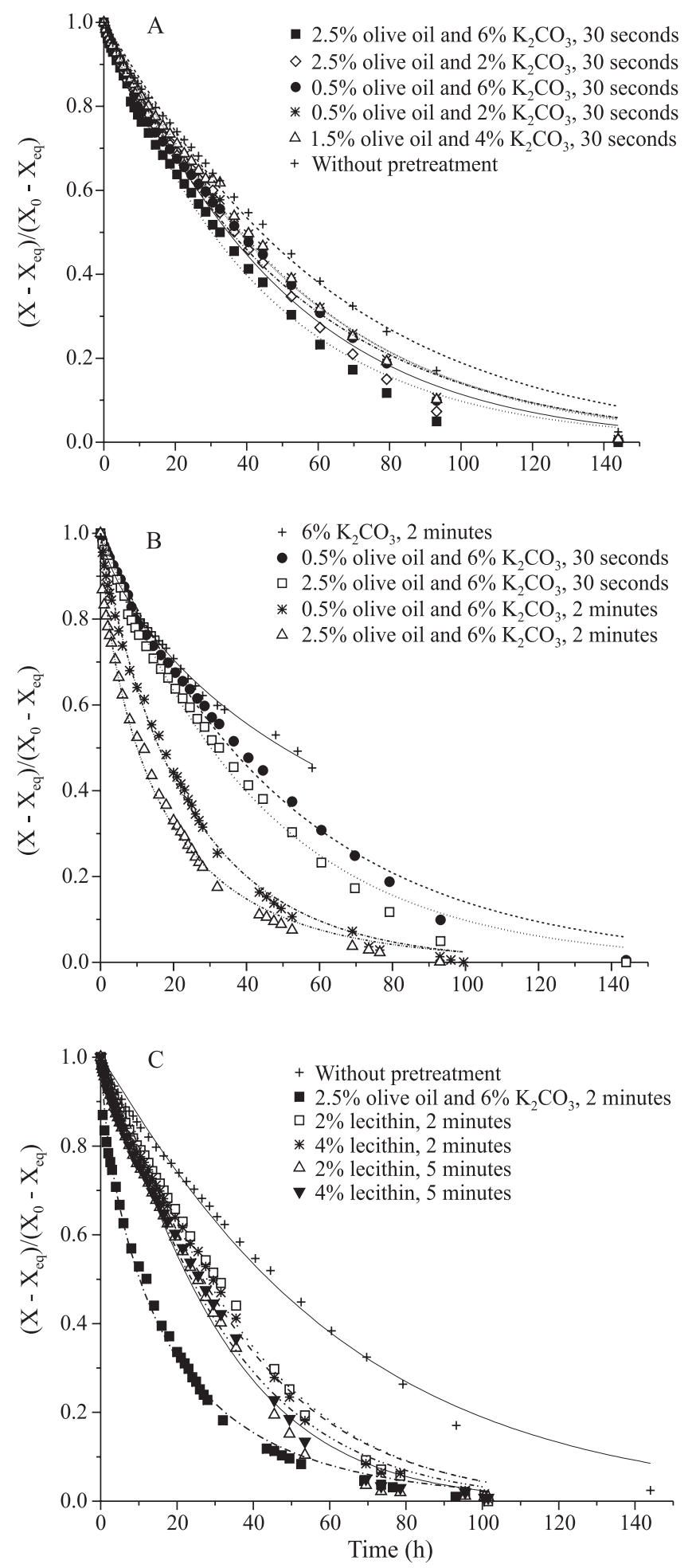

Figure 2. Drying curves for Rubi grapes dried at $50^{\circ} \mathrm{C}$ and air velocity of $1 \mathrm{~m} \mathrm{~s}^{-1}$. Traces represent the adjustment of Page model (equation 1 ). 
the mixture of olive oil and $\mathrm{K}_{2} \mathrm{CO}_{3}$, and a maximum immersion time of 2 minutes was established (Table 1 ), since longer immersion times resulted in burning of grape skin and formation of cracks. As a consequence, the raisins presented a sticky surface that was visually associated to a bad product quality.

Drying curves determined to samples pretreated in emulsions of $0.5 \%$ and $2.5 \%$ olive oil and $6 \% \mathrm{~K}_{2} \mathrm{CO}_{3}$, with immersion for 2 minutes, were compared with those obtained with immersion time of 30 seconds (Figure 2 B). Also, with the objective of clearly establishing the effect of olive oil, a drying run was conducted after immersion of grapes in a $6 \%$ solution of pure $\mathrm{K}_{2} \mathrm{CO}_{3}$. The results showed that olive oil had an important effect in accelerating drying process, since grapes pretreated with pure potassium carbonate presented the highest moisture contents at the same drying times. In addition, it was observed that increasing immersion time in alkaline solutions, during the pretreatment of grapes, was more effective to reduce drying time than increasing olive oil concentrations (Figure $3 \mathrm{~B}$ ).

Other works have already investigated the influence of pretreatments with olive oil and $\mathrm{K}_{2} \mathrm{CO}_{3}$ on drying kinetics of grapes, however no results were obtained to allow comparison between different concentrations of

Table 2. Drying times (DT) necessary to attain about 14\% moisture (wet basis) and Page model parameters for Rubi grapes dried at $50^{\circ} \mathrm{C}$ and air velocity of $1 \mathrm{~m} \mathrm{~s}^{-1}$, submitted to various chemical pretreatments ${ }^{(1)}$.

\begin{tabular}{|c|c|c|c|c|c|}
\hline Pretreatment & $\mathrm{DT}^{(2)}(\mathrm{h})$ & $\mathrm{k}\left(\mathrm{h}^{-1}\right)$ & $\mathrm{n}$ & $\mathrm{R}^{2}$ & $\overline{\mathrm{RMS}}$ \\
\hline Without pretreatment & 204.6 & 0.0122 & 1.067 & 0.994 & 4. \\
\hline $2.5 \%$ olive oil and $6 \% \mathrm{~K}_{2} \mathrm{CO}_{3}{ }^{(3)}$ & 152.7 & 0.0221 & 1.011 & 0.993 & 24 \\
\hline $2.5 \%$ olive oil and $2 \% \mathrm{~K}_{2} \mathrm{CO}_{3}{ }^{(3)}$ & 158.0 & 0.0149 & 1.082 & 0.992 & 15 . \\
\hline $0.5 \%$ olive oil and $6 \% \mathrm{~K}_{2} \mathrm{CO}_{3}{ }^{(3)}$ & 180.1 & 0.0188 & 1.010 & 0.993 & 11. \\
\hline $0.5 \%$ olive oil and $2 \% \mathrm{~K}_{2} \mathrm{CO}_{3}{ }^{(3)}$ & 176.3 & 0.0143 & 1.067 & 0.994 & \\
\hline $1.5 \%$ olive oil and $4 \% \mathrm{~K}_{2} \mathrm{CO}_{3}{ }^{(3)}$ & 172.2 & 0.0127 & 1.095 & 0.992 & \\
\hline $0.5 \%$ olive oil and $6 \% \mathrm{~K}_{2} \mathrm{CO}_{3}{ }^{(4)}$ & 95.0 & 0.0533 & 0.923 & 0.997 & \\
\hline $2.5 \%$ olive oil and $6 \% \mathrm{~K}_{2} \mathrm{CO}_{3}{ }^{(4)}$ & 93.3 & 0.1277 & 0.734 & 0.994 & \\
\hline $6 \% \mathrm{~K}_{2} \mathrm{CO}_{3}^{(4)}$ & 447.9 & 0.0373 & 0.747 & 0.998 & \\
\hline $2 \%$ lecithin $^{(4)}$ & 112.3 & 0.0138 & 1.176 & 0.992 & 29 \\
\hline $4 \%$ lecithin ${ }^{(4)}$ & 113.1 & 0.0165 & 1.137 & 0.992 & 25 \\
\hline $2 \%$ lecithin $^{(5)}$ & 96.0 & 0.0189 & 1.148 & 0.992 & \\
\hline $4 \%$ lecithin $^{(5)}$ & 103.5 & 0.0204 & 1.113 & 0.992 & \\
\hline
\end{tabular}

${ }^{(1)} \mathrm{k}$ and $\mathrm{n}$ : parameters of Page equation; $\mathrm{R}^{2}$ : correlation coefficient; RMS: root mean square of residuals. ${ }^{(2)}$ Drying times estimated by the equation $\mathrm{M}=\frac{\mathrm{X}-\mathrm{X}_{\mathrm{eq}}}{\mathrm{X}_{0}-\mathrm{X}_{\mathrm{eq}}}=\exp \left(-\mathrm{kt}^{\mathrm{n}}\right)$, adopting initial moisture content of $84 \%$ (wet basis) and equilibrium moisture content of $1.4 \%$ (wet basis). (3)Immersion for 30 seconds. ${ }^{(4)}$ Immersion for 2 minutes. ${ }^{(5)}$ Immersion for 5 minutes. olive oil and $\mathrm{K}_{2} \mathrm{CO}_{3}$ (Pangavhane et al., 1999; Vazquez et al., 1999; Pahlavanzadeh et al., 2001; Doymaz \& Pala,
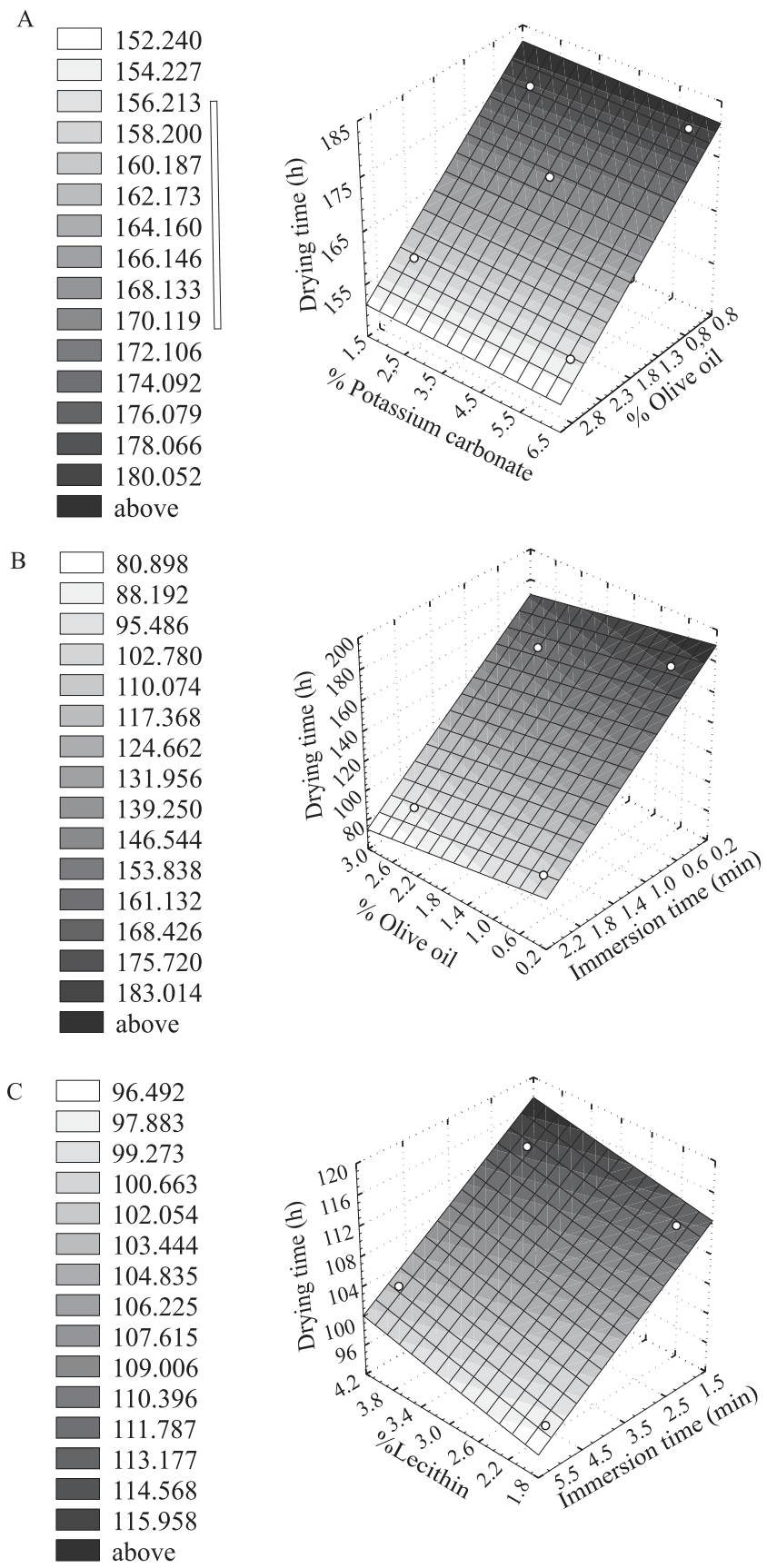

Figure 3. Effect of pretreatment conditions on drying time necessary to produce grapes with final moisture content of $14 \%$ (wet basis). (A) Different olive oil and $\mathrm{K}_{2} \mathrm{CO}_{3}$ concentrations with immersion time of 30 seconds. at $50^{\circ} \mathrm{C}$. (B) Different olive oil concentrations and immersion times in a $6 \% \mathrm{~K}_{2} \mathrm{CO}_{3}$ solution at $50^{\circ} \mathrm{C}$. (C) Different lecithin concentrations and immersion times at $50^{\circ} \mathrm{C}$. 
2002; Torul \& Pehlivan, 2004). Although most of these works have used dipping emulsions with 0.4 or $0.5 \%$ of olive oil, and 5 or $7 \%$ of $\mathrm{K}_{2} \mathrm{CO}_{3}$, there is a great discrepancy between immersion times adopted, which varied from 20 seconds to 5 minutes. Drying conditions were also very different. For a pretreatment with $0.4 \%$ olive oil in $7 \% \mathrm{~K}_{2} \mathrm{CO}_{3}$ solution, for 3 minutes at ambient temperature, and convective drying with air at $60^{\circ} \mathrm{C}$ and $0.5 \mathrm{~m} \mathrm{~s}^{-1}$, Pangavhane et al. (1999) obtained $\mathrm{k}=0.0615 \mathrm{~h}^{-1}$ (equation 1), which is somewhat higher than the value of $0.0533 \mathrm{~h}^{-1}$ found in the present work for similar pretreatment conditions. The difference could be attributed to the longer immersion time of the pretreatment and to the higher drying temperature used in that work. Doymaz \& Pala (2002) observed a reduction of $54.2 \%$ in the drying time of grapes treated with $5 \% \mathrm{~K}_{2} \mathrm{CO}_{3}$ plus $5 \%$ olive oil, when comparing with drying time of grapes without pretreatment at the same drying temperature $\left(60^{\circ} \mathrm{C}\right)$. In this work, a similar reduction of drying time (53.6\%) was observed, when comparing drying of grapes treated with $6 \% \mathrm{~K}_{2} \mathrm{CO}_{3}$ plus $5 \%$ olive oil, for 2 minutes, with nontreated grapes.

From the results presented above, it was possible to conclude that, when using traditional dipping emulsions of olive oil and potassium carbonate, the immersion time during pretreatment assumes a preponderant role, which could be attributed to a low reaction rate of the active components of the emulsion, and the constituents of the waxy layer of grape skin. During treatment with alkaline solutions, attention should be drawn to the necessary immersion time to increase water vapor permeability through grape skin and the maximum immersion time to avoid crack formation and burning of grape skin. This would require a great degree of control during processing, which is not always feasible in small processing plants. An alternative of practical interest would be to avoid the use of alkaline substances during pretreatment, which could be possible by using soy lecithin - a natural surfactant - in order to eliminate or modify the structure of the grape skin waxy layer.

Drying curves obtained after pretreatments, in dispersions of 2 and $4 \%$ of soy lecithin with immersion times of 2 and 5 minutes (Table 1), showed that lecithin was effective to accelerate drying process when comparing with untreated grapes (Figure $2 \mathrm{C}$ ). In addition, a surface plot of drying times as affected by immersion time and lecithin concentration showed that, although neither of the variables was significant at $5 \%$ level, increasing immersion time in the lecithin suspension was more effective to reduce drying time than increasing lecithin concentration (Figure 3C).

Comparison of drying curves of lecithin treated grapes with that of grapes treated with olive oil and $\mathrm{K}_{2} \mathrm{CO}_{3}$, however, demands a more careful analysis. At the initial stage of drying, moisture contents of grapes treated in the alkaline emulsion were considerably lower than those observed in lecithin treated grapes at the same drying times. Nevertheless, at the end of the process, the drying curve of grapes treated with olive oil and $\mathrm{K}_{2} \mathrm{CO}_{3}$ assumed an asymptotic behavior, resulting in a very small change of moisture content with time. At the same time, the drying curve of grapes immersed for 5 minutes in lecithin dispersions showed a continuous decrease in moisture content that led to similar total drying times (Table 2).

It was observed that treatments with lecithin resulted in the highest $\mathrm{n}$ values, indicating that there was not a reduction in drying rates at low moisture contents (Table 2). When pretreatment was carried out in the $2.5 \%$ olive oil and $6 \% \mathrm{~K}_{2} \mathrm{CO}_{3}$ emulsion for 2 minutes, the lowest value of $n$ was obtained, showing that with this treatment the drying rate decreased along the process. This behavior might be attributed to the deposition of olive oil on grapes surface, which could be visually detected by the oily aspect of the raisins resulted from this treatment.

This work presented some preliminary results, that must be further investigated, in order to determine the best treatment conditions, as well as to investigate the mechanism of action of lecithin on the waxy layer of grape skin. It is also important to point out that drying times presented in Table 2 are superestimated, since they were calculated using Page model fittings, which showed a weak agreement to experimental data at low moisture contents. Also, the convective drying temperature could be increased from 50 to $60^{\circ} \mathrm{C}$, in order to accelerate dehydration.

\section{Conclusions}

1. The most effective treatment to accelerate drying process is an emulsion of $0.5 \%$ of olive oil and $6 \%$ of $\mathrm{K}_{2} \mathrm{CO}_{3}$, at $50^{\circ} \mathrm{C}$, with immersion time of 2 minutes.

2. Increasing the immersion time of grapes in the chemical treatment reduces drying time.

3. Treatments with lecithin result in the highest $n$ values in Page model, whereas the treatment with 
$2.5 \%$ olive oil and $6 \% \mathrm{~K}_{2} \mathrm{CO}_{3}$ emulsion for 2 minutes results in the lowest value of $n$.

\section{References}

ALMEIDA, G.V.B. de. Mercado interno: a uva no contexto do mercado de frutas. In: CONGRESSO BRASILEIRO DE VITICULTURA E ENOLOGIA, 10., 2003, Bento Gonçalves. Anais. Bento Gonçalves: Embrapa Uva e Vinho, 2003. p.161-165. (Embrapa Uva e Vinho. Documentos, 40).

BOLIN, H.R.; STAFFORD, A.E. Fatty acid esters and carbonates in grape drying. Journal of Food Science, v.45, p.754-755, 1981.

BOX, G.E.P.; HUNTER, W.G.; HUNTER, J.S. Statistics for experimenters: an introduction to design, data analysis and model building. New York: Wiley, 1978. 653p.

CAMARGO, U.A. Melhoramento genético: variedades de uvas sem sementes para o Brasil. In: CONGRESSO BRASILEIRO DE VITICULTURA E ENOLOGIA, 10., 2003, Bento Gonçalves. Anais. Bento Gonçalves: Embrapa Uva e Vinho, 2003. p.171-172. (Embrapa Uva e Vinho. Documentos, 40).

DI MATTEO, M.; CINQUANTA, L.; GALIERO, G.; CRESCITELLI, S. Effect of a novel physical pretreatment process on the drying kinetics of seedless grapes. Journal of Food Engineering, v.46, p.83-89, 2000.

DOYMAZ, I.; PALA, M. The effects of dipping pretreatments on air-drying rates of the seedless grapes. Journal of Food Engineering, v.52, p.413-417, 2002.

FENNEMA, O.R. Food chemistry. $3^{\text {rd }}$ ed. New York: Marcel Dekker, 1996. 1069p.

GABAS, A.L.; MENEGALLI, F.C.; TELIS-ROMERO, J. Effect of chemical pretreatment on the physical properties of dehydrated grapes. Drying Technology, v.17, p.1215-1226, 1999.

GABAS, A.L.; TELIS-ROMERO, J.; MENEGALLI, F.C. Permeabilidade da casca de uva Itália. Brazilian Journal of Food Technology, v.1, p.90-96, 1998.

GRNCAREVIC, M.; LEWIS, W.J. Drying of grapes in Australia. Food Technology in Australia, v.28, p.66-76, 1976.

HOSSAIN, M.A.; BALA, B.K. Thin-layer drying characteristics for green chilli. Drying Technology, v.20, p.489-505, 2002.
LEWICKI, P.P. Raoult's law based food water sorption isotherm. Journal of Food Engineering, v.43, p.31-40, 2000.

NACHTIGAL, J.C. Avanços tecnológicos na produção de uvas de mesa. In: CONGRESSO BRASILEIRO DE VITICULTURA E ENOLOGIA, 10., 2003, Bento Gonçalves. Anais. Bento Gonçalves: Embrapa Uva e Vinho, 2003. p.167-170. (Embrapa Uva e Vinho. Documentos, 40).

NICOLETI, J.F.; TELIS-ROMERO, J.; TELIS, V.R.N. Air-drying of fresh and osmotically pre-treated pineapple slices: fixed air temperature versus fixed slice temperature drying kinetics. Drying Technology, v.19, p.2175-2191, 2001.

PAHLAVANZADEH, H.; BASIRI, A.; ZARRABI, M. Determination of parameters and pretreatment solution for grape drying. Drying Technology, v.19, p.217-226, 2001.

PANGAVHANE, D.R.; SAWHNEY, R.L.; SARSAVADIA, P.N. Effect of various dipping pretreatment on drying kinetics of Thompson seedless grapes. Journal of Food Engineering, v.39, p.211-216, 1999.

PARTI, M. Evaluation of diffusion based drying models: their bases and limitations. Hungarian Journal of Industrial Chemistry, v.26, p.221-228, 1998.

PONTING, J.D.; McBEAN, D.M. Temperature and dipping treatment effects on drying rates and drying times of grapes, prunes and other waxy fruits. Food Technology, v.24, p.1403-1406, 1970.

RAMOS, I.N.; SILVA, C.L.M.; SERENO, A.M.; AGUILERA, J.M. Quantification of microstructural changes during first stage air drying of grape tissue. Journal of Food Engineering, v.62, p.159-164, 2004.

STATSOFT INC. (Tulsa, Estados Unidos). Statistica for Windows. Tulsa, 1995. 1 CD-ROM.

TORUL, I.T.; PEHLIVAN, D. Modelling of thin layer drying kinetics of some fruits under open-air sun drying process. Journal of Food Engineering, v.65, p.413-425, 2004.

VAZQUEZ, G.; CHENLO, F.; MOREIRA, R.; CARBALLO, L. Desorption isotherms of muscatel and aledo grapes, and the influence of pretreatments on muscatel isotherms. Journal of Food Engineering, v.39, p.409-414, 1999.

WANG, J. A single-layer model for far-infrared radiation drying of onion slices. Drying Technology, v.20, p.1941-1953, 2002. 